\title{
What You Need to Apply for Disaster Rehabilitation Assistance
}

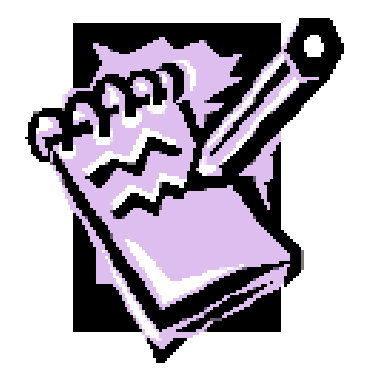

- This publication was written by Regina Fegan and Michael T. Olexa, Food and Resource Economics Department, University of Florida.

- This document, IFAS publication DH0438, was published June 1998 revised May 2003. It is part of The

Disaster Handbook, a component of the Comprehensive Disaster Preparedness and Recovery Education Module; General editor: Carol J. Lehtola, Agricultural and Biological Engineering Department, Institute of Food and Agricultural Sciences, University of Florida, Gainesville, Florida 32611.

For information about products and ordering, please visit:

$<$ http://disaster.ifas.ufl.edu>. UF/IFAS Extension publications are available at the EDIS Web site: $<$ http:/ledis.ifas.ufl.edu>.

- The Institute of Food and Agricultural Sciences is an equal opportunity / affirmative action employer authorized to provide research, educational information, and other services only to individuals and institutions that function without regard to race, color, sex, age,

handicap, or national origin. For information on obtaining other extension publications, contact your county Cooperative Extension Service office. Florida Cooperative Extension Service / Institute of Food and Agricultural Sciences / University of Florida / Christine Taylor Waddill, Dean.
After a disaster, you may need to seek financial assistance to restore your home or farm. There are many sources of assistance, but you will be required to provide certain information. The lists below can help you assemble the necessary information before you meet with any agents.

What you will need for most grants or loans:

- Itemized list of losses.

- Estimates of the repair or replacement cost of each item.

- Estimates of new flood insurance premiums.

- Federal income tax returns from the last three years (copies).

- Deed, mortgage, or renter's lease (copy).

- Previous insurance policy or insurance settlement (copy).

For personal loss:

- Proof of monthly income (stubs, statements).

- Driver's license and/or Social Security Number.

Business or farm loss:

- A brief history of the business or farm.

- Personal and business financial statements.

- Loan repayment schedule.

- List of bills owed.

- Agricultural Stabilization and Conservation Service information on farm crop base and assigned yields.

\section{Sources for This Publication}

The Disaster Handbook for Extension Agents University of Wisconsin Extension. Access on the Web at: $<$ http://www.uwex.edu/ces/news/handbook.htm> 
This publication is designed to provide accurate, current, and authoritative information on the subject. However, since the laws, regulations, administrative rulings, and court decisions on which it is based are subject to constant revision, portions of this publication could become outdated at any time. This publication is distributed with the understanding that the authors are not engaged in rendering legal advice or opinions, and the information contained herein should not be regarded, or relied upon, as a substitute for legal advice or opinion. For these reasons, the utilization of these materials by any person constitutes an agreement to hold harmless the authors, the Institute of Food and Agricultural Sciences and the University of Florida for any liability claims, damages or expenses that may be incurred by any person as a result of reference to or reliance on the information contained in this fact sheet.

The Disaster Handbook Institute of Food and Agricultural Sciences University of Florida
What You Need to Apply for Disaster Rehabilitation Assistance Section 4.38

Page 2 